\title{
Pleural effusion in Iraq: a prospective study of 100 cases
}

\author{
FA AL-ALUSI \\ From the College of Medicine, University of Baghdad, Medical City Hospital, Baghdad, Iraq
}

Pleural effusion is a common condition encountered by both chest physicians and chest surgeons in Iraq, and diagnosis of the cause is often difficult. The relative frequency of causes of pleural effusion are known to vary in different parts of the world. ${ }^{1-3}$ This prompted us to study the causes of pleural effusion in Iraq, and also to evaluate the laboratory methods currently being used in our hospital for the diagnosis of this condition.

\section{Methods}

This study was based on a prospective survey of 100 consecutive patients presenting with pleural effusion who were admitted to a general medical ward from January 1982 to February 1985 . Sixty three were male and 37 female. Their ages ranged from 14 to 80 years (mean 38.5 years). A clinical history was obtained and a physical examination carried out on every patient. A chest radiograph was obtained and sputum when present was examined for the presence of acid fast bacilli and subjected to cytological examination. Pleural fluid was aspirated and its appearance noted. Protein and glucose content were measured, white blood cell and differential counts were obtained, and the fluid was subjected to cytological examination.

Table 1 Causes of pleural effusion in 100 cases

$\left.\begin{array}{lrc}\hline \text { Cause } & & \begin{array}{c}\text { No of } \\ \text { patients }\end{array} \\ \hline \begin{array}{l}\text { Tuberculosis } \\ \text { Malignancy }\end{array} & 38 \\ \begin{array}{l}\text { Bronchial carcinoma } \\ \text { Metastatic carcinoma (breast, cervix, stomach) }\end{array} & \begin{array}{r}11 \\ \text { Lymphoma }\end{array} & \\ \begin{array}{l}\text { Mesothelioma } \\ \text { Myeloma }\end{array} & 5 \\ \begin{array}{l}\text { Ewing's tumour (of the rib) } \\ \text { Other infective conditions }\end{array} & 1 \\ \begin{array}{l}\text { Postpneumonic } \\ \text { Pleural hydatid disease }\end{array} & 1\end{array}\right\}$

Address for reprint requests: Dr FA Al-Alusi, Department of Medicine, College of Medicine, University of Baghdad, Baghdad, Iraq.

Accepted 13 December 1985
Table 2 Results of pleural biopsy in 38 cases of tuberculous and 34 of malignant effusion

\begin{tabular}{|c|c|c|}
\hline Eventual diagnosis & Result & No of cases (\%) \\
\hline $\begin{array}{l}\text { Tuberculosis } \\
\text { Malignancy }\end{array}$ & $\begin{array}{l}\text { Diagnostic } \\
\text { Non-diagnostic } \\
\text { Unsuccessful } \\
\text { Diagnostic } \\
\text { Non-diagnostic } \\
\text { Not done }\end{array}$ & $\begin{array}{c}18(47) \\
17(45) \\
3(8) \\
14(61) \\
9(39) \\
11\end{array}$ \\
\hline
\end{tabular}

Pleural biopsy was carried out with Abram's needle, one $\vec{\varphi}$ attempt being made in most cases. A tuberculin test was carried out with $0.1 \mathrm{ml}(2 \mathrm{TU})$ of PPD and the result was considered positive when after 72 hours $10 \mathrm{~mm}$ of induration or more was seen. Bronchoscopy was performed when it was thought to be indicated. Other haematological, biochemical, and serological tests were undertaken when they were considered necessary, and in some patients lymph node biopsy was performed.

\section{Results}

The most frequent cause of pleural effusion was tuberculosis, which occurred in 38 patients, of whom 30 were adolescents or young adults. Malignant disease accounted for 34 cases 을 (table 1). In six patients no cause for the pleural effusion was $\underset{\times}{\varnothing}$ found. The most common symptoms were dyspnoea in $87 \%$ and cough in $86 \%$; fever was present in $79 \%$ and chest pain 3 . in $67 \%$. Twelve of the 38 patients with tuberculosis produced sputum; in only one case was the sputum positive for acid fast bacilli on direct examination. Cytological examination of the sputum showed malignant cells in eight of $19 \mathrm{~S}$ patients with malignant disease who produced sputum. The $\rightarrow$ pleural fluid appeared straw coloured in $34(90 \%)$ of the tuberculous effusions and haemorrhagic in $25(73 \%)$ of the malignant cases. The pleural fluid was an exudate in the - great majority of tuberculous and malignant cases and also $N$ in cases associated with pneumonia, pulmonary infarction, $N$ systemic lupus erythematosus, and hydatid disease. It was $\sigma$ transudate when it was part of a generalised accummulation of fluid in the body. The concentration of glucose in the pleural fluid in 30 of the 36 tuberculous cases in which it was examined was over $60 \mathrm{mg} / 100 \mathrm{ml}(>3.33 \mathrm{mmol} / \mathrm{l})$, while in ? six it was $60 \mathrm{mg} / 100 \mathrm{ml}$ or less. In 20 of the effusions due to $\underline{T}$ bronchial or metastatic carcinoma the glucose concentration ranged from 65 to $185 \mathrm{mg} / 100 \mathrm{ml}(3.61-10.27 \mathrm{mmol} / \mathrm{l})$, while

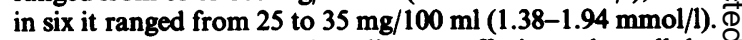
In both tuberculous and malignant effusions the cellular $\frac{O}{\sigma}$ content of the fluid was predominantly lymphocytic $(80-100 \%$ of the total leucocyte count). In malignant cases 
the fluid was positive for malignant cells in $15(60 \%)$ out of 25 patients. The results of pleural biopsy are shown in table 2 .

\section{Discussion}

This study indicates clearly that tuberculosis is still the most common single cause of pleural effusion in Iraq. Cancer is, however, becoming more common as a cause than it was a decade ago. ${ }^{4}$ The relative frequency of the two most common causes of pleural effusion, tuberculosis and cancer, differs from that found in other countries. ${ }^{1-3}$ There may be several explanations for this difference, but perhaps the most important is that tuberculosis is still not an uncommon disease in Iraq. In this country tuberculous pleural effusion is mainly a disease of adolescents and young adults. A similar age distribution was found in developed countries 30 or $\mathbf{4 0}$ years ago, when tuberculosis was still prevalent there. Apart from the history and the physical findings, we have found that the two most useful diagnostic methods were pleural biopsy as a means of differentiating between tuberculosis and malignancy and cytological examination of fluid as a means of confirming the diagnosis.

In other types of effusion a combination of the clinical features of the accompanying disease and the results of relevant tests were usually adequate to make the diagnosis. Our experience of the value of examination of the biochemical and cellular content of the pleural fluid resembles that reported in other studies. ${ }^{1245}$ Cytological examination of the pleural fluid yielded positive results in $15(60 \%)$ out of 25 malignant effusions, which compares well with other studies, where the proportion ranged from $15 \%$ to $70 \% .^{126-8}$

Pleural biopsy was diagnostic in almost $61 \%$ of cases of malignant disease; similar studies have produced figures ranging from $29 \%$ to $60 \% .{ }^{1278}$ The diagnostic yield of $47.3 \%$ in tuberculous cases was, however, rather low compared with the results of others. ${ }^{29}$ The tuberculin test gave a positive result in most patients with tuberculous effusions as expected. It was also positive, however, in $25 \%$ of patients with non-tuberculous effusion, reflecting the high prevalence of tuberculosis in Iraq.

In the patient with pleural effusion due to hydatid disease the pleura was studded with small hydatid cysts, although no cyst could be detected in the lung itself. Ultrasound examination performed before the thoracotomy had shown the presence of multiple liver cysts.

In Iraq, whenever pleural effusion is seen in an adolescent or young adult the most likely cause is tuberculosis. Malignancy, whether pulmonary, metastatic, or of lymphatic origin, may be becoming an increasingly common cause of pleural effusion in this country. Pleural biopsy and cytological examination of the pleural fluid were the most helpful diagnostic investigations available in this study.

\section{References}

1 Hirsch A, Ruffie P, Nebut M, Bignon J, Chretien J. Pleural effusion: laboratory tests in 300 cases. Thorax 1979;34:106-12.

2 Storey DD, Dines DE, Coles DT. Pleural effusion, a diagnostic dilemma. JAMA 1976;236:2183-6.

3 Branch WT, McNeil BJ. Analysis of the differential diagnosis and assessment of pleuritic chest pain in young adults. Am J Med 1983;75:871-9.

4 Bakir F, Al-Ani F, Talib H, Thwaini J, Al-Shabander N, Rasheed RK. Serous lymphocytic exudate in Iraq: the value of various methods of investigations. Tubercle 1977;58:101-7.

5 Yam LT. Diagnostic significance of lymphocytes in pleural effusion. Ann Intern Med 1967;66:972-82.

6 Dhillon DP, Spiro SG. Malignant pleural effusion. Br J Hosp Med 1983;29:506-9.

7 Sahn SA. The differential diagnosis of pleural effusion. West $J$ Med 1982;137:99-108.

8 Salyer WL, Eggleston JC, Erozan YS. Efficacy of pleural needle biopsy and pleural fluid cytopathology in the diagnosis of malignant neoplasm involving the pleura. Chest 1975;67:536-9.

9 Onadeko BO, Abioye AA. Needle biopsy of the pleura in Nigeria. Br J Dis Chest 1979;73:282. 